УАK 005.35:631.1

O. Yermakov,

Doctor of Economic Sciences, Professor, Professor of the Department

of Economics, National University of Life and Environmental Sciences of Ukraine

ORCID ID: 0000-0001-5070-6528

V. Nahornyi,

PhD in Economics, Associate Professor, Associate Professor of the Department

of Economics, National University of Life and Environmental Sciences of Ukraine

ORCID ID: 0000-0001-5551-4779

DOI: $10.32702 / 2306-6792.2021 .23 .17$

\title{
ON THE ISSUE OF DEVELOPMENT OF CORPORATE SOCIAL RESPONSIBILITY OF AGRICULTURAL BUSINESS ENTITIES
}

\author{
О. Ю. Ермаков, \\ А. е. н., професор, професор кафедри економіки, \\ Національний університет біоресурсів і природокористування України \\ B. В. Нагорний, \\ к. е. н., доцент, доцент кафедри економіки, \\ Національний університет біоресурсів і природокористування України
}

\section{АО ПИТАННЯ РОЗВИТКУ КОРПОРАТИВНОЇ СОЦІААЬНОЇ ВІАПОВІАААЬНОСТІ СУБ'СКТІВ АГРАРНОГО БІЗНЕСУ}

The article examines the methodological principles of corporate social responsibility (CSR) development in the agricultural sector of Ukraine. The advantages of implementing the CSR system in the practice of Ukrainian agrarian formations are substantiated on the example of IMK agricultural holding. The main incentives that will contribute to the spread of corporate social responsibility are identified, and the main directions of CSR development in agribusiness are proposed.

Corporate social responsibility of agrarian business entities can be interpreted as a process of implementation of voluntarily accepted obligations to meet the social needs of employees of the business entity, as well as partners and other members of society in general.

IMK is one of the 10 largest agricultural companies in Ukraine. It is an integrated economic entity that carries out its activities in such areas as growing crops (sunflower, soybeans, wheat, corn) and storage of products; milk production. The company pursues an active social policy in the following areas: personnel, labor and health protection, industrial safety, environmental protection, social program "IMK helps".

Regarding this agrarian formation, the following can be stated: first, an important component is environmental protection and resource conservation, as corporate and social business must take comprehensive initiatives to reduce the harmful effects of its production and economic activities on the environment; second, politics socially responsible companies should provide social programs for residents of the region of business, which include support for socially vulnerable groups, support for the preservation and development of housing and communal services and cultural and historical sites, etc.; thirdly, the development of the company's staff should be aimed at training and professional development, taking into account the maintenance of a high level of motivation employees, both in terms of pay and social package, the creation of appropriate conditions for recreation and leisure, support of internal communications in the company, as well as the active participation of the personnel of the business entity in management decisions.

The main directions of increasing the level of competitiveness of "IMK" on the basis of the development of corporate social responsibility are implementation of the policy of responsible attitude of the company to its employees; support, and development of the position of active citizenship; initiating a dialogue with influence groups as a tool for obtaining 
information on optimizing social programs and minimizing enterprise risks; introduction of reporting standards in its social responsibility program; creation of separate subdivisions, the introduction of separate positions that will be responsible for CSR management activities; increase of the company's budgets for CSR activities. All this will improve the business reputation and image among the population, consumers and customers, investment attractiveness of the company, and more.

У статті досліджено методологічні засади розвитку корпоративної соціальної відповідальності (КСВ) в аграрному секторі України. Обгрунтовано на прикладі агроходдингу "IMК" переваги впровадження системи КСВ у практику українських аграрних формувань. Визначено основні стимули, які сприятимуть поширенню корпоративної соціальній відповідальності, та запропоновано основні напрями розвитку КСВ в аграрному бізнесі.

Корпоративну соціальну відповідальність суб'єктів аграрного бізнесу можна трактувати як процес реалізації Аобровільно прийнятих зобов'язань із задоволення соціальних потреб як працівників господарюючого суб'єкта, так і партнерів та інших учасників суспільства загалом.

"IMK" є однією 3 10-ти найбільших аграрних компаній в Україні. Це інтегрований господарюючий суб'єкт, що зАійснює свою Аіяльність за такими напрямами: вирощування сільськогосподарських культур (соняшник, соя, пшениця, кукуруАза) та зберігання їх продукції; виробництво молока. Компанія проводить активну соціальну політику в таких напрямах: персонал, охорона праці та здоров'я, промислова безпека, охорона навколишнього середовища, соціальна програма "IMK допомагає".

3 приводу цього аграрного формування можна констатувати наступне: по-перше, важдивою складовою є природоохоронна діяльність і ресурсозбереження, оскільки корпоративно-соціальний бізнес повинен зАійснювати комплексні ініціативи по скороченню шкідливої дії своєї виробничо-господарської діяльності на довкілля; по-друге, політика соціально- відповідальних компаній повинна передбачати соціальні програми Аля жителів регіону ведення бізнесу, які включають підтримку соціально незахищених верств населення, підтримку збереження і розвитку житлово-комунального господарства і об'єктів культурно-історичного значення та ін.; по-третє, розвиток персоналу компанії має бути направлений на навчання та професійний розвиток, враховуючи піАтримку високого рівня мотивації працівників, що стосується як оплати праці, так і надання соціального пакету, створення належних умов Аля відпочинку і дозвіляя, підтримка внутрішніх комунікацій в компанії, а також активна участь персоналу господарюючого суб'єкта в ухваленні управлінських рішень.

Основними напрямами підвищення рівня конкурентоспроможності "IMК" на основі розвитку корпоративної соціальної відповідальності є: впровадження політики відповідального ставлення компанії до своїх найманих працівників, підтримка та розвиток позиції активного громадянства; започаткування діалогу із групами впливу, як інструмент отримання інформації щодо оптимізації соціадьних програм та мінімізації ризиків підприємства; введення станАартів звітності у своїй програмі соціальної відповідальності; створення окремих підрозділів, введення окремих посаА, що відповідатимуть за Аіяльність з управління КСВ; збільшення бюджетів компанії на заходи з КСВ. Все це Аасть змогу покращити Аілову репутацію та імідж сереА населення, споживачів та клієнтів, інвестиційну привабливість компанії тощо.

Key words: agricultural sector, corporate social responsibility, agrarian formations, competitiveness, economy.

Ключові слова: аграрний сектор, корпоративна сочіальна відповідальність, аграрні формування, конкурентоспроможність, економіка.

\section{FORMULATION OF THE PROBLEM}

Prospects for the development of agrarian business in the world economic space provide for further solution by producers of issues related to the implementation of mechanisms of corporate social responsibility in the practice of modern management.

This has become especially acute and relevant in the agricultural sector of Ukraine, because domestic agricultural enterprises, as its main organizational unit, have undergone the most radical and large-scale transformations in terms of ownership, land use, production organization, resource supply and sales, etc. [4].

Nowadays, in order to function successfully in a market environment, agricultural producers must develop strategic and marketing programs of their companies based on social responsibility policy in order to gain additional competitive advantage. This is due to the fact that the obligation to comply with CSR initiatives is defined by many international documents, and without proper implementation of which agribusiness entities can not effectively conduct their business activities in world markets for agri-food products. Thus, the implementation of CSR initiatives for Ukrainian agricultural formations is a mandatory element of strategic development.

\section{ANALYSIS OF RECENT RESEARCH AND PUBLICATIONS}

Issues related to corporate social responsibility have been reflected in the works of such foreign 


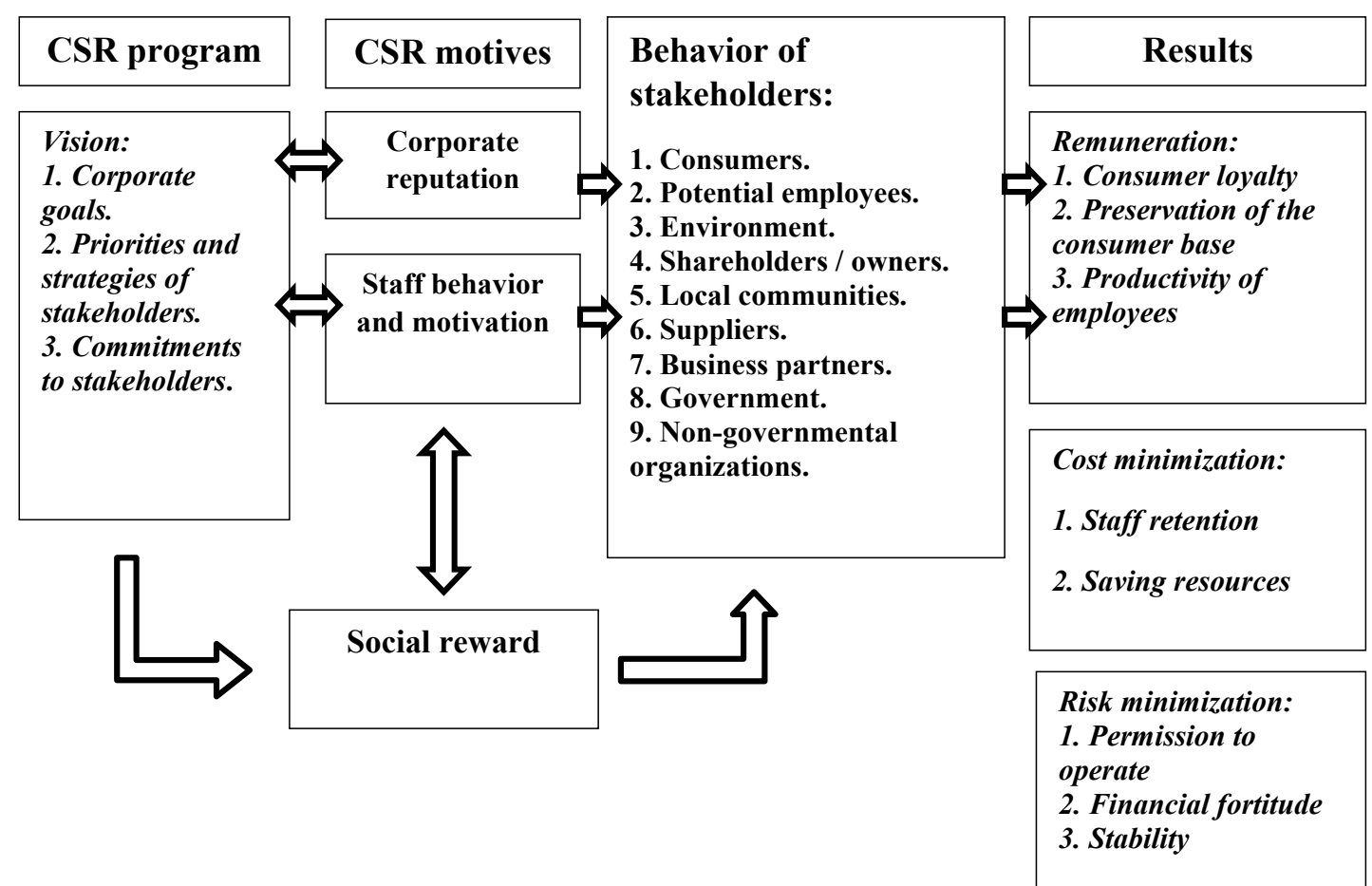

Fig. 1. The mechanism of CSR formation at the enterprise

Source: [1].

scholars as Becker G., Vienna K., Davis K., Kotler F., Kramer M., Porter M. and others. In Ukraine, research on corporate social responsibility, including in the agricultural sector, is carried out by: D.O. Bayura, V.P. Galushko, O.A. Grishnova, I.Y. Grishova, O.O. Yerankin, O.Yu. Yermakov, T.O.Zinchuk, A.M. Kolot, V.V. Kuzhel, P.M. Makarenko, O.O. Lazarenko, V.V. Nahornyi and others.

However, given the extreme importance of the development of corporate social responsibility in the agricultural business of Ukraine in the context of increasing its competitiveness, there is an urgent need to study these issues.

\section{THE PURPOSE OF THE ARTICLE}

The purpose of the article is to study the features of corporate social responsibility and determine the main directions of its development in the agrarian business of Ukraine.

Object of study: social and economic processes of formation and development of corporate social responsibility in the agricultural sector of Ukraine.

Subject of study: organizational - economic bases of development of corporate social responsibility of subjects of agrarian business and their features in the modern business environment.

Materials and methods of research. The subject of the research covers methodological and practical principles of development of corporate social responsibility of agrarian business entities. Research methods: abstract-logical, monographic, graphic, etc.

\section{PRESENTATION \\ OF THE MAIN MATERIAL}

Corporate social responsibility is a system of economic, social, environmental measures, as well as ethical norms and values of the company, which are implemented on the basis of constant interaction with stakeholders and aimed at reducing non-financial risks, long-term improvement of the company's image and business reputation, as well as on capitalization growth, gaining competitive advantages and strategic stability of the business structure [7].

Thus, in a general sense, corporate social responsibility can be presented as a long-term commitment of business entities, including agriculture, to adhere to business ethics and promote economic development, while improving working conditions and quality of life of employees, their families and communities. and society as a whole. Undoubtedly, this is extremely important for the agricultural sector based on the peculiarities of the agricultural sector, working conditions and living conditions of its workers and so on. At the same time, in view of the decline of rural areas that took place in Ukraine, we must carefully consider the application of mechanisms of socio-economic 


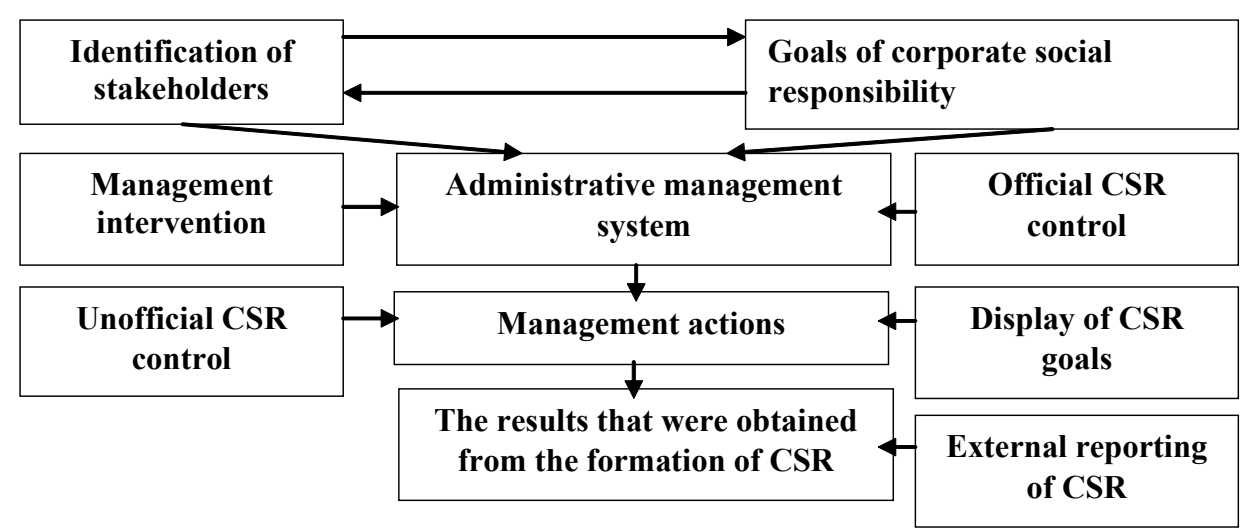

Source: [1].

Fig. 2. Organizational model of the mechanism of CSR formation at the enterprise

development, including those related to the formation and development of corporate social responsibility of agricultural businesses.

In the context of further development of the methodological foundations of this issue, we present the statement of D.O. Bayura and O.A. Buyana" - an effective mechanism for the formation of CSR in Ukraine is possible only if the adequate implementation of relations, principles and values of CSR based on the implementation of strategies that will enhance the company's reputation, brand value, staff motivation. These factors are perhaps the most important " [1, p. 155]. Next, the same researchers provide a mechanism for the formation of CSR in the enterprise (Fig. 1).

In general, this mechanism can be represented as a holistic structure consisting of the main groups of elements: program, motives, business behavior towards stakeholders and the results that the business entity will receive from the introduction of social responsibility in its activities.

We share the opinion [1, p. 155], that in order to ensure the mechanism of CSR formation at the enterprise it is necessary to introduce an organizational model, which consists of defining stakeholders, CSR goals (Fig 2).

However, in the development of the opinion of the mentioned authors we should also note that the introduction of such an organizational model of the mechanism of CSR formation at the enterprise should provide the business entity, including agrarian, not just a mechanism but an effective mechanism of corporate social responsibility.

To deepen the existing theoretical provisions on the mechanism of corporate social responsibility, it is proposed to consider it as a set of technologies for managing environmental challenges in the system of strategic management of sustainable development, which includes values, goals and objectives, principles, directions, levels of implementation, methods and forms of CSR to meet the interests of stakeholders, increase benefits, minimize costs and risks for the company in the long run, as well as monitoring the results of their effectiveness [9].

The study of the experience of spreading corporate social responsibility in the practice of managing domestic agricultural formations shows that it is on such methodological principles that the Industrial Milk Company (IMC) builds its socio-economic activity. This integrated business structure, which is one of the 10 largest agricultural formations in Ukraine, carries out its production and economic activities in such areas as: a) growing crops (sunflower, soybeans, wheat, corn); b) storage of agricultural products; c) milk production. It was founded as "Industrial Milk Company" by the former owner of the holding "Cheese Club" Alexander Petrov. In April 2017, the Industrial Milk Company officially changed its name to IMC. The general director of this powerful agrarian formation is now a talented manager Alex Lissitsa, who is a graduate of the Faculty of Economics of the National University of Life and Environmental Sciences of Ukraine.

The company's mission is to meet the vital needs of mankind in quality agricultural raw materials and products. The company aims to become a world leader for investors, employees, customers and the social community. In its daily work, IMC is guided by such principles as: responsibility, efficiency, professionalism, initiative, honesty, respect and teamwork. The company's priority is efficiency, introduction of advanced world technologies and own know-how, export orientation, sustainable development, quality and safety.

Every business structure that adheres to the concept of corporate social responsibility, develops and implements its principles in the overall strategy of its development. 
IMC development strategies are: expansion of agricultural business through the growth of the land bank in cultivation and storage capacity; focusing on operational efficiency; diversification of crop production and focusing on the most profitable; deepening vertical integration to generate additional income from the processing of agricultural raw materials.

The lands on which IMC operates are located in Poltava, Chernihiv and Sumy oblasts. These are favorable regions for agriculture in terms of soil and climatic conditions for growing crops.

The company's land bank is formed in the form of five clusters, within which the fields are in close proximity to each other. This allows you to maximize operational efficiency and reduce costs by optimizing the use of human and technical resources, as well as promote effective operational management.

IMC applies modern production and management practices in agriculture and constantly invests in the purchase of new agricultural machinery and equipment from leading global brands.

The IMC fields use a system of different tillage: deep loosening, plowing, disking and cultivation. Alternation of such technological methods allows to create optimal conditions for growth and development of agricultural crops.

The technology of growing crops in the "IMC" involves the use of seeds, fertilizers and plant protection products only the best domestic and foreign producers.

Elements of precision agriculture are tested and introduced into production: GPS-monitoring systems of equipment, autopiloting, methods of remote sensing of the earth, monitoring of productivity, variable norms of sowing of seeds and differentiated application of fertilizers [2].

"IMK" has significant capacity for storage of agricultural products (elevators and floor storage warehouses), which are located near the areas of its production activities.

The company uses only its own storage facilities. IMC's storage facilities currently $100 \%$ meet the company's storage needs and have sufficient potential to meet these needs in the short term, provided that production volumes increase.

Possession of these storage facilities enables the company to sell its agricultural products during the marketing year and significantly reduces the negative impact on prices during and after harvest, as well as reduces the risks associated with physical loss of crops [2].

It should be noted that the largest share of revenues according to the financial statements the company receives from the sale of corn $-70.4 \%$, as it specializes in growing this crop. In 2019, IMC received \$ 169.6 million. revenues from sales of manufactured products, and in $2020-161.4 \mathrm{mi}-$ llion dollars.

"IMC" carries out production activities and builds its management strategy guided by the principles of sustainable and socially responsible business development.

The basic principles of corporate social responsibility, which should be guided by the business structure:

- production of quality products and services necessary for society;

- unconditional compliance with legislation: tax, environmental, labor;

- effective business, focused on creating additional economic value and increasing competitiveness in the interests of owners and society;

- building honest and mutually beneficial relations with all stakeholders;

- compliance with international agreements and use of recommendations of international standards;

- use of resource-saving technologies, ensuring environmental safety of production;

- providing jobs with a competitive level of wages and social benefits;

- ensuring occupational safety in the workplace;

- promotion of comprehensive professional development and professional development of employees [8].

An important component of agrarian business in Ukraine is the social policy of the state. It is the support of rural development, infrastructure, the creation of appropriate conditions that would motivate people to live and work in the countryside, is the key to the availability of professionals for "IMC", its support by the community and local government.

Based on the analysis of the Corporate Social Responsibility Reports 2017/2018 and 2019/2020 [2], it can be stated that IMC is one of such companies that does not stand aside from social problems. Thus, in 2019 it sent over UAH 18.1 million. to provide social assistance to the rural population. Since 2012, the company's management has decided to combine all social efforts into one program called "IMC helps". For 12 years, since 2008. until 2020, at the expense of the company's allocated funds, the following were carried out: repairs of schools, kindergartens, medical and obstetric points, purchase and replacement of metal-plastic windows in schools and hospitals; repairs of roads, water mains and 


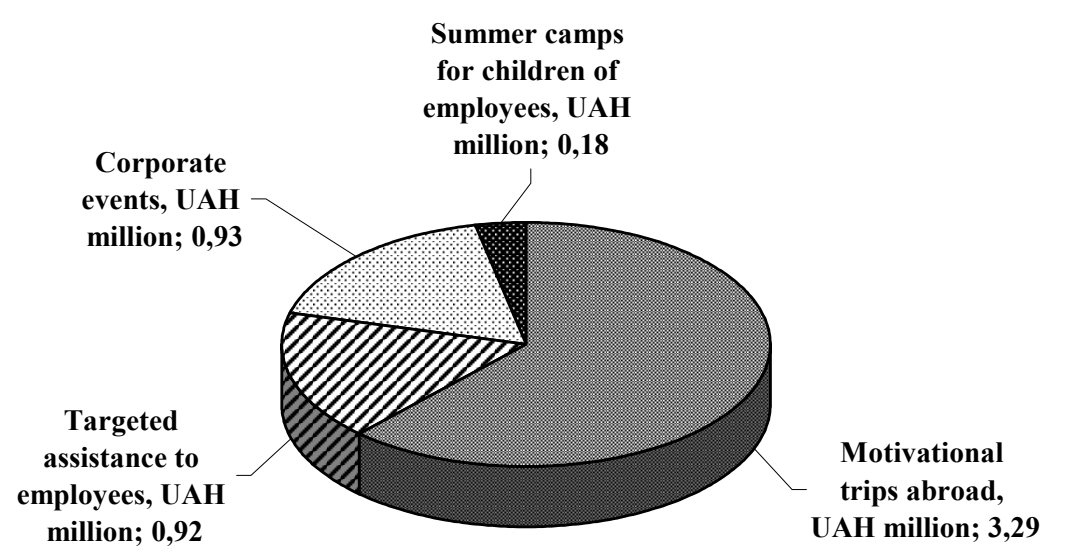

Source: [2].

Fig. 3. Expenses for motivational activities for IMC staff in 2019

lighting of settlements; purchase of equipment for district and rural hospitals and ambulances; construction of a bridge and a boarding school, financing the construction of a monument to Afghan soldiers and anti-terrorist operation soldiers; sponsorship of regional cultural events: festivals, fairs, various holidays in rural communities, funding of football teams.

The social component of IMC is carried out in the following areas: personnel of enterprises, labor protection and health, quality of the workplace, industrial safety, environmental protection, the concept of "green office" and the social program "IMC helps".

IMC provides staff with training opportunities that meet the company's strategic goals and values. Employees gain knowledge and improve their skills through specialized training programs that cover the following goals: career start, knowledge expansion, personal growth and leadership development.

Maintaining a high level of motivation among IMC employees and preventing such threats as: internal and external migration of staff, attracting young people to work in rural areas and their retention are important issues for business leaders.

Help to form staff loyalty to "IMC": organization of corporate events (team building, sports tournaments, corporate events); dissemination of motivational trips abroad and within the country for different levels of employees; stimulating contacts between clusters in various forms (working meetings, team building, training programs); active communication policy through media platforms (corporate website, company pages on Facebook, corporate newspaper "IMC Bulletin"), personal contacts with IMC headquarters and management vertical; active trainings; development of targeted assistance to employees; implementation of the housing program for employees; providing vouchers for children to children's camps.

In 2019, the company spent about UAH 1.2 million on the training program and improved the policy "On targeted assistance to employees", which allows to receive and record the amount of financial support for employees in case of difficult life circumstances, the birth of children, weddings, reimbursement of medical expenses of employees and close relatives. UAH 5.32 million was spent on motivational measures for staff (Fig. 3).

In 2019-2020, 285 IMC employees went on motivational trips to 10 countries, including about 100 mechanics and drivers.

As a socially responsible company "IMC" to increase the motivation of its own employees, uses tangible and intangible incentives.

In the field of material incentives, the company provides official employment and social protection stated by the legislation of Ukraine. According to a survey conducted by Socio Inform in February 2019 , one of the most common reasons for working in the company is the level of pay $-37.9 \%$ and the opportunity to learn and gain new experience $37.4 \%$. Also good reasons are quite favorable "microclimate" in the workforce and a high level of social protection, respectively, for $25.7 \%$ and $25.2 \%$ of employees, $23.4 \%$ said that the reason for working in the "IMC" is that here they can realize themselves as professionals.

Based on the experience of the world's leading companies, in 2016 IMC began to form a safety, health and environmental management system. In the same year, the company's 5-year strategy for professional activities "Occupational Health and Environment" for 2016-2020 was approved. All IMC enterprises are monitored in the following areas: use of natural resources and environmental legislation, occupational safety at work. The company seeks to involve all employees in the 


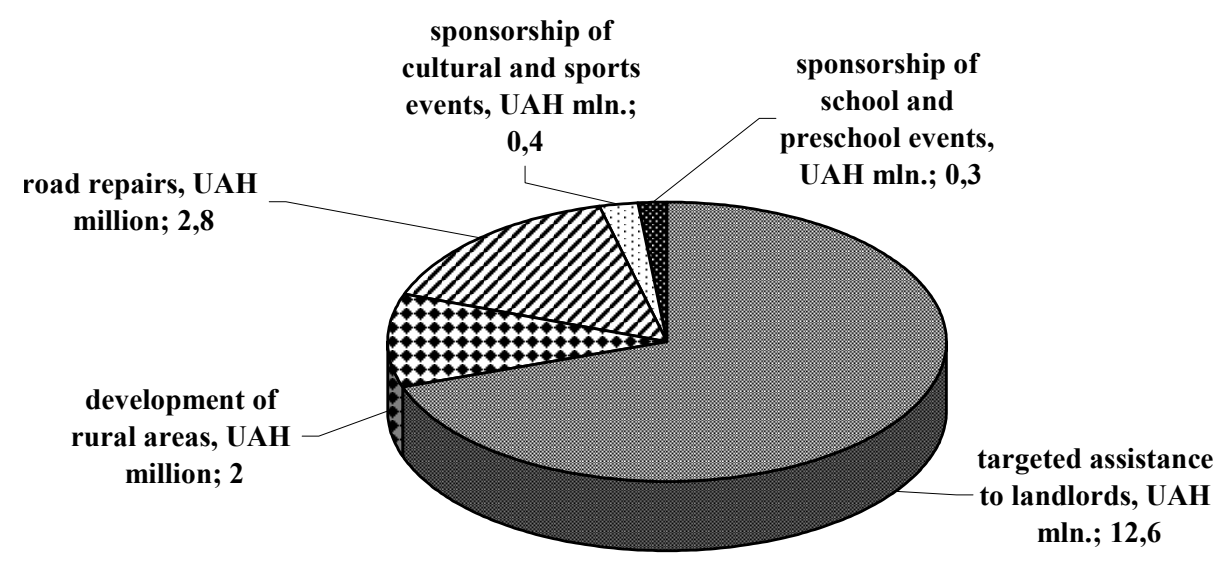

Fig. 4. IMC investments in social projects in 2019

Source: [2]

management of environmental issues, labor protection and social aspects in the "IMC" and its subsidiaries.

All investments and initiatives in social projects, including personal support and projects to support and develop local infrastructure (roads, water supply, public lighting, schools, kindergartens, FAPs, medical centers, etc.), which the company conducts within the villages where it operates, are held on the principles of "IMC. People's Aid Program". Local communities are involved in setting project priorities, budgeting and planning the necessary actions. Investments and initiatives for such projects in 2019 reached UAH 18.1 million (Fig. 4).

Thus, IMC uses social investments in the practice of management exactly where they have the greatest impact and effective result, uniting local communities, business and government.

\section{CONCLUSIONS}

Corporate social responsibility of agrarian business entities can be interpreted as a process of implementation of voluntary commitments to meet the social needs of employees of the business entity, and partners and other members of society in general.

IMC is one of the 10 largest agricultural companies in Ukraine. This is an integrated agricultural company that operates in such areas as: production of crops (sunflower, soybeans, wheat, corn); storage of crops; milk production. The company pursues social policy in the following areas: staff, health and safety, industrial safety, environmental protection, social program "IMC helps".

Several conclusions can be drawn about this agrarian formation: first, an important component is environmental protection and resource conservation, corporate and social business must take comprehensive initiatives to reduce the harmful effects on the environment; secondly, the policy of socially responsible companies should provide social programs for residents of the region of business, which include support for socially vulnerable groups, support for the preservation and development of housing and communal services and cultural and historical sites, etc.; thirdly, the development of the company's staff should be aimed at training and professional development, taking into account the maintenance of a high level of employee motivation in terms of both pay and social package, creating conditions for recreation and leisure, support of internal communications in the organization, employee participation in making management decisions.

The main directions of increasing the level of competitiveness of IMC are: implementation of the policy of responsible attitude of the company to its employees, support and development of the position of active citizenship; initiating a dialogue with influence groups as a tool for obtaining information on optimizing social programs and minimizing enterprise risks; introduction of reporting standards in its social responsibility program; creation of separate subdivisions, introduction of separate positions that will be responsible for CSR management activities; increase of the company's budgets for CSR activities. All this will improve the business reputation and image among the population, consumers and customers, the investment attractiveness of the company.

\section{References:}

1. Bayura, D.O. and Buyan, O.A. (2012), "Conceptual principles of the mechanism of formation of corporate social responsibility in Ukraine", Actual problems of economics, vol. 9, pp. 151-157.

2. The official site of "IMC" (2021), available at: https://imcagro.com.ua/ua/diyalnist-kompany/roslinnitstvo (Accessed 10 Nov 2021). 
3. Yermakov, O.Y. (2015), Sotsial'na vidpovidal'nist' [Social responsibility], CE "Comprint, Kyiv, Ukraine

4. Yermakov, O.Y. and Nahornyi, V.V. (2016), "Methodological bases of distribution of corporate social responsibility in agrarian formations of Ukraine", Naukovyj visnyk NUBiP Ukrainy, Seriia: Ekonomika, ahrarnyj menedzhment, biznes, vol. 249, pp. $165-174$.

5. Ermakov, A. and Ignatenko, N. (2015), "Financial and investment support industrial innovation and social responsibility of agricultural enterprises", Investytsiyi: praktyka ta dosvid, vol. 18, pp. 7-10.

6. Zinchuk, T.O. and Levkivsky, E.V. (2019), "Corporate social responsibility of vertically integrated structures of agrarian business as a condition of sustainable development", Ekonomika APK, vol. 1, pp. 39.

7. Kolot, A. M., Kolot, A. M., Hrishnova, O. A., Hryshnova, E. A., Herasymenko, O. O., Herasymenko, O. A., and Shevchenko, L. S. (2012), Sotsial'na vidpovidal'nist': teoriia i praktyka rozvytku [Social responsibility: theory and practice of development], KNEU, Kyiv, Ukraine

8. Povazhny, O.S. and Orlova, N.S. (2014), "Formation of corporate strategy on the basis of social responsibility", Manager, vol. 1, pp. 4-10.

9. Popadyuk, O.V. and Luchyk, O.I. (2019), "Principles and mechanism of social responsibility in terms of strategic management of the enterprise, Economics and management of enterprises", vol. 36, pp. 235-246.

10. Shapoval, V.M. (2011) Sotsial'na vidpovidal'nist' biznesu v strukturi upravlinnia ekonomikoiu [Social responsibility of business in the structure of economic management], SHEI "NMU", Dnipropetrovsk, Ukraine

11. Yermakov, O.Y., Hrebennikova, A.A., Nahornyi, V.V., and Chetveryk, O.V. (2019), "Investment support and development of social responsibility of agrarian business entities", Proceedings of the $34 \mathrm{rd}$ International Business Information Management Association Conference (IBIMA), Madrid. Spain.

12. Nahorniy, V. V. and Chetveryk, O. V. (2017), "The problem of implementing social responsibility in Ukraine agro-industrial enterprises capacity", Science and Education a New Dimension, vol. 24 (146), pp. 7-11.

\section{$\Lambda$ ітература:}

1. Баюра А.О., Буян О.А. Концептуальні засади механізму формування корпоративної соціальної відповідальності в Україні. Актуальні проблеми економіки. 2012. № 9. С. 151-157.
2. Аіяльність компанії "IMK". URL: https:// imcagro.com.ua/ua/diyalnist-kompany/roslinnitstvo

3. Єрмаков О.Ю. Соціальна відповідальність: навчальний посібник. Київ: ЦП "Компринт", 2015. $191 \mathrm{c.}$

4. Єрмаков О.Ю., Нагорний В.В. Методологічні засади поширення корпоративної соціальної відповідальності в аграрних формуваннях України. Науковий вісник НУБіП України. Серія: Економіка, аграрний менеджмент, бізнес. 2016. Вип. 249. С. 165174.

5. Єрмаков О.Ю., Ігнатенко М.М. Фінансово-інвестиційне забезпечення виробничих інновацій та соціальної відповідальності аграрних підприємств. Інвестиції: практика та досвід. 2015. № 18. C. 7-10.

6. Зінчук Т.О., Аевківський Є.В. Корпоративна соціальна відповідальність вертикально інтегрованих структур аграрного бізнесу як умова сталого розвитку. Економіка АПК. 2019. № 1. C. 39.

7. Колот А.М., Колот А.М., Грішнова О.А., Гришнова Е.А., Герасименко О.О., Герасименко О.А.,... \&атр; Шевченко М.С. Соціальна відповідальність: теорія і практика розвитку: монографія, за ред. А.М. Колота. Київ: КНЕУ, $2012.501 \mathrm{c}$.

8. Поважний О.С., Орлова Н.С. Формування корпоративної стратегії на основі соціальної відповідальності. Менеджер. 2014. № 1. С. 410. URL: http://nbuv.gov.ua/UJRN/Nzhm_2014_1_3

9. Попадюк О.В., Аучик О.І. Принципи та механізм соціальної відповідальності в умовах стратегічного управління підприємством. Економіка та управління підприємствами. 2019. № 36. С. $235-246$.

10. Шаповал B.M. Соціальна відповідальність бізнесу в структурі управління економікою: монографія. Аніпропетровськ: $А \mathrm{BH}$ "НГУ", 2011. 357 с.

11. Yermakov O.Yu., Hrebennikova A.A., Nahornyi V.V., and Chetveryk O.V. Investment support and development of social responsibility of agrarian business entities. Proceedings of the 34 rd International Business Information Management Association Conference (IBIMA). Madrid, 2019. Spain.

12. Nahorniy V.V. and Chetveryk O.V. The problem of implementing social responsibility in Ukraine agro-industrial enterprises capacity. Science and Education a New Dimension. 2017. Vol. 24 (146), P. 7-11.

Стаття надійщла до редакиії 26.11.2021 p. 